\title{
A PRODUÇÃO EDITORIAL NA AG COMUNIQUE: APROXIMAÇÕES COM A PEDAGOGIA DE PAULO FREIRE ${ }^{1}$
}

\author{
Denis Carvalho Carneiro ${ }^{2}$ \\ Luiza Giordano Cardassi ${ }^{3}$ \\ Marcelo Fernando de Lima ${ }^{4}$ \\ Paulo Henrique Borges 5
}

Resumo: O presente trabalho tem como objeto de pesquisa a AG Comunique, agência experimental do Curso de Comunicação Institucional da UTFPR. A partir da ótica do pensamento do teórico de Paulo Freire, são apontadas similaridades de suas ideias com a construção e a execução da agência. É demonstrada também a relevância deste veículo em quanto ao desenvolver acadêmico e profissional dos alunos.

Palavras-chave: Comunicação, educação, Paulo Freire, agência experimental.

Abstract: The aim of this essay is to study AG Comunique, an experimental communication agency created by the course of Institutional Communication of UTFPR. By using theoretical discussions of Paulo Freire, we point out similarities between his thought and ideas that formed the agency. We also demonstrate the importance of the agency for the students' academic and professional development.

Keywords: Communication, education, Paulo Freire, experimental communication agency.

\section{Introdução}

O objetivo deste trabalho foi realizar uma análise do projeto da AG Comunique (www.agcomunique.wordpress.com), agência de notícias experimental do Curso Superior de Tecnologia em Comunicação Institucional da Universidade Tecnológica Federal do Paraná (CTCOM-UTFPR). A agência foi criada em março de 2013 para oferecer aos alunos um espaço de prática da disciplina de Laboratório de Produção de Textos Jornalísticos (LPTJ), ministrada pelo professor e jornalista Marcelo Fernando de Lima. O embasamento teórico deste trabalho partiu das ideias de Paulo Freire relacionadas à educação e à comunicação. A pesquisa de campo consistiu na realização de entrevistas com alunos e professores que, de forma direta e indireta, participaram da agência.

A AG Comunique foi implantada no início de março de 2013; logo depois de sua criação, os alunos já começaram a produção de conteúdo jornalístico. Com o passar do tempo, novos

\footnotetext{
${ }^{1}$ Pesquisa realizada dentro do projeto "Comunicação e recepção", ao longo do ano letivo de 2014, sob orientação do professor Dr. Marcelo Fernando de Lima, do Departamento Acadêmico de Linguagem e Comunicação da Universidade Tecnológica Federal do Paraná (DALIC-UTFPR) e com a colaboração da professora Dra. Maurini de Souza.

${ }^{2}$ Graduado em Comunicação Institucional pela UTFPR.

${ }^{3}$ Graduada em Comunicação Institucional pela UTFPR.

${ }^{4}$ Doutor em Letras (UFPR), professor-adjunto da UTFPR.

${ }^{5}$ Graduado em Comunicação Institucional pela UTFPR.
} 
DITO EFEITO - ISSN 1984-2376 - v. 6, n. 8, jan./jun. 2015 - UTFPR CURITIBA - http://periodicos.utfpr.edu.br/de

estudantes passaram a contribuir com o site, inclusive os que não estavam matriculados na disciplina. Com o aumento do número das matérias, a agência ganhou corpo e tornou-se uma importante ferramenta de comunicação para os alunos.

O presente trabalho foi articulado em três segmentos: no primeiro, fazemos uma exposição sobre a criação da agência e sua relação com o projeto pedagógico do curso de Comunicação Institucional e da própria filosofia da UTFPR; no segundo, discutimos as ideias de Paulo Freire que relacionam conceitos de educação e comunicação; no terceiro, apresentamos pontos de vistas sobre a agência colhidos entre professores e alunos que participaram direta ou indiretamente de sua produção. Ao final do estudo são apresentadas sugestões para a melhoria da agência.

\section{Uma agência de notícias para o CTCOM-UTFPR}

A AG Comunique, criada para os alunos do quarto período do curso de Comunicação Institucional para a disciplina de Laboratório de Produção de Textos Jornalísticos (LPTJ), completou dois anos em março de 2015, apresentando 300 postagens. A criação da agência está ligada à própria característica da instituição, pois a UTFPR “possui em seu DNA a vocação para o ensino de conhecimentos e habilidades voltados, essencialmente, para o mercado de trabalho" 6 . Atividade prática, a agência serve como instrumento de incentivo à prática da produção de textos jornalísticos.

Criada em 2005, a UTFPR teve sua origem numa instituição que surgiu em 1910 e, tendo por vocação o ensino tecnológico, foi se adaptando às necessidades locais quanto à formação de trabalhadores. Assim, surgiu como Escola de Aprendizes e Artífices, em 1910. Mais tarde, tornou-se Liceu Industrial do Paraná; nos anos seguintes, mudanças na legislação nacional refletiram na instituição, quando o ensino industrial passou a funcionar em ciclos e foi criada a rede federal de instituições de ensino industrial, mudando assim para Escola Técnica de Curitiba (1942); no ano em que o ensino técnico foi unido, passou a ser conhecida como Escola Técnica Federal do Paraná (1959).

Em 1974, foram inseridos os primeiros cursos de curta duração, nas áreas de Construção Civil e Elétrica. Quatro anos depois, houve uma das principais mudanças em sua história, quando passou a ser o Centro Federal de Educação Tecnológica do Paraná (CEFET-PR). Foram iniciados os cursos de graduação plena. Com a mudança, a instituição foi deixando aos poucos o ensino de crianças e adolescentes, recebendo em sua maioria jovens e adultos. Nas décadas seguintes, foram implantados os cursos de pós-graduação, e em 1990, foram criados novos campi.

Em 1996, a Lei de Diretrizes e Bases da Educação (LDB) obrigou a instituição a não mais

6 Conheça a UTFPR, a primeira universidade tecnológica do país. Disponível em <http://redeglobo .globo.com/globouniversidade/noticia/2013/10/conheca-utfpr-primeira-universidade- tecnologica-do-pais.html $>$ Acesso: 1 ago. 2014. 
ofertar cursos técnicos integrados, passando assim a receber apenas alunos do ensino médio e cursos de tecnologia. Dois anos depois, ainda por conta das alterações implantadas pela LDB, começou o projeto para a implantação da universidade. Após sete anos e o aval do governo federal, foi criada a primeira universidade tecnológica do Brasil, em 7 de outubro de 2005. Atualmente, a UTFPR conta com 13 campi e cerca de 31 mil alunos.

Durante o processo de transformação em universidade, foi inaugurado no ainda CEFETPR o Curso de Tecnologia em Comunicação Empresarial e Institucional, em 2003, por professores do Departamento de Comunicação e Expressão (DACEX), responsável até então pelas disciplinas de Língua Portuguesa na instituição. Atualmente, o curso foi extinto e substituído pelo Bacharelado em Comunicação Organizacional, com carga horária mais ampla e maior oferta de vagas. O curso está ligado ao Departamento Acadêmico de Linguagens e Comunicação (DALIC), que substituiu o DACEX.

O objetivo do curso, desde seu início, foi o de formar profissionais que tivessem conhecimento em várias áreas da comunicação, qualidade de escrita e domínio de ferramentas dessa área de atuação, sendo capazes de trabalhar em jornais, sites, revistas, agências de comunicação, empresas privadas, terceiro setor, além de outras possibilidades. Apesar de ter sido oficialmente concebido como um curso de tecnologia, a ênfase sempre esteve voltada para uma "sólida base cultural e generalista, características de um curso mais amplo, como um bacharelado" $"$

A primeira turma ingressou na instituição em 2004, e dois anos depois o nome do curso foi alterado. Por conta do Decreto $n^{\circ}$ 5.773/06 do Ministério da Educação, sobre as Diretrizes Curriculares Nacionais, passou a se chamar Curso de Tecnologia em Comunicação Institucional (CTCOM). Dentro do curso, eram ministradas matérias nas áreas de Português, Marketing, Jornalismo, Relações Públicas, Publicidade, Estatística, Editoração Eletrônica, Linguagem Visual, Psicologia, Eventos, História, Legislação, Ética, Inglês. Segundo seu projeto pedagógico, o curso:

\footnotetext{
[...] permite aos seus egressos uma gama de oportunidades a partir da amplitude adotada para a tecnologia em comunicação institucional. Assim, forma profissionais dotados de competências e habilidades para atuarem em diversas organizações públicas, privadas ou do terceiro setor, como executivos e gestores de comunicação, assessores de imprensa, analistas de comunicação interna e externa, analistas de marketing, assessores políticos, redatores, diretores de criação, atendimento e executivos comerciais, produtores de eventos, consultores, profissionais liberais, além de toda uma gama de novas profissões com a utilização cada vez maior das mídias digitais. Também há um viés importante ligado à área do empreendedorismo, voltada para a criação de produtoras de audiovisual ou empresas de eventos.
}

$\mathrm{Na}$ formação do comunicador institucional, o estudo da Língua Portuguesa e da

\footnotetext{
${ }^{7}$ UTFPR. Projeto Pedagógico do Curso de Tecnologia em Comunicação Institucional. Departamento 
DITO EFEITO - ISSN 1984-2376 - v. 6, n. 8, jan./jun. 2015 - UTFPR CURITIBA - http://periodicos.utfpr.edu.br/de

Linguística é trabalhado em vários períodos, diretamente em matérias como Noções e Uso da Norma Culta, Laboratório de Textos Dissertativos, Laboratório de Textos Publicitários, Laboratório de Textos Jornalísticos, e de forma indireta em algumas outras, como Laboratório de Textos Empresariais e Institucionais e Laboratório de Textos Multimídia.

Tendo como base as questões relativas à Análise do Discurso, o CTCOM busca desenvolver três habilidades pessoais, que levam em consideração o social e o humano. A primeira é o saber linguístico, que implica em um aprimoramento de sua língua materna, criando uma base sólida para as relações humanas e profissionais do egresso. A partir disso, chega-se ao segundo ponto, o saber enciclopédico, que consiste em aprender variados conteúdos e técnicas de acordo com sua área de atuação. Fechando o ciclo, é explorado o saber interacional, que pode ser compreendido como a união do saber técnico com conhecimentos humanísticos, com o objetivo de criar uma comunicação estruturada, eficaz e ética.

Para aprender técnicas e compreender ferramentas utilizadas pela área, "o acadêmico tem à disposição também conhecimentos em várias mídias e linguagens tecnológicas que favoreçam a geração e a veiculação da comunicação empresarial e institucional ${ }^{8}$ " . Essa afirmação está alinhada à missão da UTFPR, que é "promover a educação de excelência através do ensino, pesquisa e extensão, interagindo de forma ética e produtiva com a comunidade para o desenvolvimento social e tecnológico".

Em 2007, o Catálogo Nacional dos Cursos Superiores de Tecnologia, publicado pelo Ministério da Educação, afirma que o CTCOM está em conformidade com constantes mudanças econômicas, tecnológicas e sociais do país, frutos da globalização e de outros fatores externos. Relativamente novo na área, o Comunicador Institucional tem a função de "gerenciar" a comunicação, e para isso é necessário um amplo conhecimento de suas nuances.

Para uma introdução teórica e prática da área de jornalismo, os alunos do CTCOM têm em sua grade a disciplina de Laboratório de Produção de Textos Jornalísticos que tem como bases tecnológicas:

[...] os gêneros do texto jornalístico (crônica, editorial, opinião, artigos, release, entrevista); apuração de dados; técnica de coleta de dados; estrutura da notícia; o texto noticioso; tipos de título; hierarquia das matérias; interpretação e opinião; edição: a intenção da edição; a pauta e sua importância; a ética do texto jornalístico; leitura, crítica e produção de texto jornalístico. ${ }^{9}$

Como competências, os alunos devem "aplicar as técnicas de coleta de dados para uma notícia; utilizar os diferentes gêneros do texto jornalístico; redigir textos jornalísticos; realizar divulgação científica e informação científica, diferenciando os gêneros do jornalismo científico". Antes de o professor Marcelo Fernando de Lima assumir a disciplina, os alunos produziam um

\footnotetext{
${ }^{8}$ UTFPR. Projeto Pedagógico do Curso de Tecnologia em Comunicação Institucional. Departamento

Acadêmico de Comunicação e Expressão (DACEX). Curitiba, 2013.

${ }^{9}$ Idem.
} 
DITO EFEITO - ISSN 1984-2376 - v. 6, n. 8, jan./jun. 2015 - UTFPR CURITIBA - http://periodicos.utfpr.edu.br/de

jornal impresso, sob orientação da professora Maurini de Souza. Durante o semestre, os alunos aprendiam o funcionamento teórico e prático da produção de conteúdo de um jornal, inclusive dividindo os cargos, como o editor, o pauteiro e os responsáveis pela parte comercial do jornal.

Havia também a separação de editorias, e cabia ao professor, além de ensinar a teoria, o papel de administrador da produção, com poucas intervenções no funcionamento prático cabendo aos alunos as verdadeiras responsabilidades. Com isso, em um semestre os alunos aprendiam conceitos teóricos do jornalismo no mesmo período que exercitavam a prática. Como resultado, podemos destacar a publicação de 20 textos jornalísticos e a viabilização econômica da impressão do jornal.

No segundo semestre de 2012, novos professores ingressaram na UTFPR por meio de concurso público, e quatro deles da área de Comunicação. Por conta disso, algumas matérias tiveram seus professores alterados, como LPTJ. Com a bagagem que trazia de 13 anos ministrando aula no Curso de Jornalismo da Universidade Positivo, o professor Marcelo Fernando de Lima apostou na criação da agência experimental AG Comunique. Em março de 2013, com três semanas de aula e a ideia já formatada pelo professor e pelos alunos, foi fundada a AG Comunique. Além de participar do processo de escolha do nome e do funcionamento da agência, ficou a cargo dos alunos a criação de mecanismos de comunicação como a elaboração do site da fanpage no Facebook e de perfil no Twitter.

A prática da profissão de comunicador institucional, ou de jornalista, é valorizada na disciplina, cabendo ao professor o papel de editor-chefe. Os alunos trazem de suas vivências gostos ou interesses pessoais os assuntos tratados pela AG Comunique, deixando o ambiente mais diversificado e com a "cara" dos estudantes. Com isso, a disciplina se transforma em uma redação, em que os próprios alunos definem temas, metas e os objetivos da publicação.

É importante destacar que a criação de AG Comunique possibilitou também a divulgação de conteúdo por meios eletrônicos, fazendo com que a informação pudesse chegar a todos os lugares do mundo, uma das muitas vantagens sobre o jornal impresso. Segundo as estatísticas do site da AG Comunique, até a data de análise (12 de agosto de 2014) já haviam sido produzidas 248 postagens, com 49.907 visualizações. Além do acesso no Brasil (cerca de 47,5 mil desse total) a página eletrônica da AG Comunique já foi acessada por usuários de outros 46 países, com destaque para os Estados Unidos, Portugal, Alemanha e Reino Unido.

Com alguns meses de existência do projeto, foi possível criar o primeiro conteúdo especial da agência, fazendo com que todos os alunos produzissem sobre o mesmo tema - mas com enfoques diferentes. Em decisão coletiva com os alunos, o professor optou por colocar o Mercado Municipal de Curitiba como tema central e no dia 11 de abril de 2013 começou a série especial. Foram abordados assuntos como a fidelização do cliente como estratégia de venda; sobre um restaurante com mais de 35 anos de funcionamento no local; a opinião dos comerciantes sobre a nova "cara" do mercado; produtos japoneses; a ala de alimentos orgânicos do mercado, entre 
DITO EFEITO - ISSN 1984-2376 - v. 6, n. 8, jan./jun. 2015 - UTFPR CURITIBA - http://periodicos.utfpr.edu.br/de

outros. Outro conteúdos temáticos foram publicados com turmas posteriores, tais como uma "blitz" jornalística na rua Riachuelo (área de Curitiba que havia sido revitalizada recentemente) e eventos (encontros de comunicação, eleições, Dia da Consciência Negra).

Independente da ligação com outras disciplinas, a AG Comunique é um canal aberto para todos os alunos do curso expressarem suas opiniões e produzirem conteúdo jornalístico. Como para os alunos matriculados na disciplina, os interessados em produzir conteúdo para a AG passam pela aprovação do professor Marcelo.

\section{Paulo Freire na AG Comunique}

Para análise da AG Comunique, escolhemos conceitos de Paulo Freire que entrelaçam a educação à comunicação. Venício Lima (2011, p. 33) destaca: "Freire equipara educação com comunicação, uma vez que não apenas utiliza ambos os termos indistintamente, mas também os iguala em sua epistemologia". Seu processo educativo parte do princípio de que o ser humano é o sujeito de sua própria formação, que deve ser feita a partir da interação com outros sujeitos, com diálogo e de forma horizontalizada. Assim, a opinião e reflexão dos sujeitos independe de seu nível intelectual e de aprendizado. A comunicação horizontal, ou bidirecional, se dá no diálogo entre o educando e professor.

O educador coloca-se no mesmo nível dos educandos, facilitando o diálogo. Esta é a ideia de construção do conhecimento, diferentemente da simples transmissão e transferência, questionada por Paulo Freire. Esta forma diferenciada de educação permite que o ser humano seja e se sinta valorizado dentro do meio a que pertence, não mais sendo tratado como um sujeito passivo. "O homem não é uma ilha. É comunicação. Logo, há uma estreita relação entre comunhão e busca. [...] A educação tem caráter permanente. Não há seres educados. Estamos todos nos educando. Existem graus de educação, mas estes não são absolutos (FREIRE, 1979, p. 28)".

Freire propõe a transformação do sujeito passivo em sujeito crítico: ele não está no mundo para se adaptar, mas para questionar a realidade e buscar mudanças. Diz o pedagogo (1978, p. 75): “[...] meu papel no mundo não é só o de quem constata o que ocorre, mas também o de quem intervém como sujeito de ocorrências. Não sou apenas objeto da história, mas seu sujeito igualmente". O educador ainda ressalta a importância dada aos saberes dos educandos durante o processo de ensino. A partir dessa valorização, é possível utilizar estes saberes como experimentos pedagógicos acerca da realidade de cada sujeito.

Por isso mesmo pensar certo coloca a o professor ou, mais amplamente, à escola, o dever de não só respeitar os saberes com que os educandos, sobretudo os das classes populares, chegam a ela [...] mas também [...] discutir com os alunos a razão de ser de alguns desses saberes em relação com o ensino dos conteúdos (FREIRE, 2011, p. 31).

Cabe relacionar esta ideia com a rotina de produção da AG Comunique, em que se percebe 
o incentivo por parte do professor com relação à opinião e aos conhecimentos dos alunos da disciplina para a execução de tarefas, presentes nas sugestões de pauta, realização de matérias jornalísticas e proposição de melhorias para o veículo.

A comunicação é entendida como um importante instrumento para Paulo Freire, pois ela permite que os sujeitos se relacionem entre si e com seu educador. Neste processo, tanto o emissor quanto o receptor aprendem, e ambos tornam-se sujeitos de sua própria educação. A partir dessa concepção, o contexto de aprendizado educacional transcende o social, pois o sujeito começa a entender melhor sua realidade, passando a questioná-la e, por fim, a buscar melhorias. Assim, entendemos as ideias de Freire e a importância da comunicação à educação, buscando soluções para um fim social. Para o pedagogo, a missão da educação é um compromisso com a mudança social.

Para pensar a mudança, é necessário que a comunicação seja participativa, popular e horizontalizada, em que os sujeitos, em uma forma de diálogo, trocam informações visando o desenvolvimento da consciência crítica de uma determinada comunidade para, então, tornaremse transformadores de sua realidade:

\footnotetext{
[...] somente um ser que é capaz de sair de seu contexto, de "distanciar-se" dele para ficar com ele; capaz de admirá-lo, para objetivando-o, transformá-lo e, transformandoo, saber-se transformado pela sua própria criação; um ser que é e está sendo no tempo que é o seu, um ser histórico, somente este é capaz, por tudo isto, de comprometer-se (FREIRE, 1979, p. 6).
}

O pensamento de Freire fornece subsídios para o entendimento da AG Comunique, levando em conta seu processo de criação, desenvolvimento, produção, mas também o relacionamento professor-aluno, como veremos a seguir.

A disciplina LPTJ conta como responsável o professor Marcelo Fernando de Lima desde 2013. No processo de ensino e auxílio aos alunos na disciplina, o educador teve autonomia para iniciar o projeto da agência. Esta liberdade "cedida" pela universidade pôde tornar a disciplina moldável a suas ideias e à sua experiência como jornalista e professor em outra instituição por mais de uma década. Além disso, o professor pôde, durante a produção de material para a agência, conhecer melhor seus alunos, entender seus gostos pessoais e experiências, permitindo que eles produzissem um conteúdo que lhes fosse mais adequado, próximo de seu cotidiano e em muitos casos questionando suas próprias realidades.

A autonomia permitiu uma dinâmica de produção. A experiência dos alunos e do professor, além dos conteúdos produzidos para a agência servindo de alimento para a publicação na internet, movimentaram o projeto e o fizeram crescer. A agência não apenas faz parte de uma disciplina, mas também tornou-se parte da rotina dos alunos do curso. E por fim, a agência passou a fazer parte da rotina dos leitores. Os mesmos que publicam seus textos podem conhecer outros pontos de vista - e sugerir melhorias às questões sociais. Freire salienta que o educador 
deve

[...] saber que ensinar não é transferir conhecimento, mas criar possibilidades para a sua própria educação ou na sua construção. Não apenas precisa ser aprendido por ele e pelos educandos nas razões de ser - ontológica, política, ética, epistemológica, pedagógica -, mas também precisa ser constantemente testemunhado, vivido (2011, p. 47).

Para este processo acontecer, o desenvolvimento do aluno deve ser contínuo, o diálogo deve ocorrer de maneira horizontalizada, em que não há somente disseminação de informação, mas sim uma comunicação baseada no ir e vir, sem hierarquia ou dominação. É possível afirmar que este tipo de comunicação pode ocorrer nos meios on-line. A horizontalização ocorre, por exemplo, no espaço de comentários de blogs, em que os leitores podem opinar. Além da caixa de comentários, os alunos apresentam suas matérias no Facebook da agência e, também, em suas contas pessoais. Esta veiculação possibilita que qualquer pessoa que veja o conteúdo possa lê-lo e comentá-lo. É a possibilidade de comunicação direta, em consonância com as ideias de Freire:

\footnotetext{
[...] a tradição da comunicação como um diálogo ganha renovada importância e potencializa a possibilidade da interação permanente e on-line no próprio ato da comunicação. Freire teorizou a comunicação interativa antes da revolução digital, vale dizer, antes da internet e de suas redes sociais. Como fez o próprio Freire, devemos nos remeter às suas reflexões sobre a teoria do conhecimento, base do conceito de comunicação como diálogo (LIMA, 2011, p. 22).
}

Nesse processo, os alunos têm liberdade de buscar informação com independência. $\mathrm{O}$ papel do professor é fazer adequações quanto a questões gramaticais, estruturais e relacionados à ética jornalística. Mesmo assim, trata-se de um processo negociado: os textos não precisam seguir um formato jornalístico engessado; os alunos têm liberdade de experimentar formas e conteúdos novos. A autonomia proposta pelo professor vai ao encontro da preocupação de Freire em mostrar que a educação é responsabilidade do educando, responsável (sujeito) pela própria formação acadêmica e social, em diálogo com o professor. Tal responsabilidade possibilita que ele desenvolva novas ideias, concepções, questione regras estabelecidas e possa escolher seu próprio método de aprendizado e desenvolvimento das técnicas jornalísticas. Além disso, não somente o aluno desenvolve seu aprendizado, já que nesta comunicação horizontalizada o professor aprende com o estudante.

Conforme depoimento do professor Marcelo, "o perfil editorial vai se moldando de acordo com os perfis das pessoas que produzem o veículo, com grande liberdade" (LIMA, 2014). Exemplo disso é que o aluno tende a abordar temas que estão mais próximos ou com os quais possui mais afinidade, diferentemente do que ocorre nos grandes veículos de comunicação comercial, em que as pautas são definidas a partir dos interesses das empresas de comunicação. Além disso, por meio da AG Comunique o aluno compreende e reflete sobre sua própria realidade. 


\title{
Relato de participantes da AG Comunique
}

As entrevistas realizadas para este trabalho levaram em conta questões como a adoção da agência experimental no lugar do jornal impresso na disciplina de LPTJ; a importância dos projetos pedagógicos e agências experimentais na universidade; a evolução do aluno no contexto acadêmico e social por meio do trabalho na agência; e a similaridade de algumas ideias de Paulo Freire com o processo de produção na AG Comunique na própria percepção de entrevistados. Foram ouvidos professores e alunos envolvidos com a agência.

O primeiro tópico é a mudança do jornal impresso para a agência na internet. A professora Maurini (SOUZA, 2014) declarou:

\begin{abstract}
[...] não vejo muitas diferenças, a questão é a adequação ao meio. Enquanto a agência acaba sendo mais fácil de se acessar para os que se inserem no mundo digital (não amassa, não suja as mãos, possui a ferramenta de busca, o hipertexto amplia as escolhas do leitor quanto às informações complementares), o jornal impresso atinge as pessoas que são excluídas daquele mundo e também possibilitando o acesso em qualquer lugar para qualquer pessoa. Ambos são abrangentes nas suas possibilidades.
\end{abstract}

O estudante Luís Fernando Franzen participou da disciplina de LPTJ anteriormente à criação da agência, em 2010, época em que os alunos produziam conteúdo jornalístico e, ao reunir as matérias, era produzido um jornal impresso. Para ele

\footnotetext{
[...] o jornal era uma grande ferramenta de publicação dos próprios alunos do CTCOM. Era um grande orgulho poder assinar um conteúdo trabalhado e realizado por nós mesmos. Porém, como o jornal tinha um custo elevado, não podíamos produzir e publicar muitas matérias. Com isso, ficávamos restritos à pouca produção, e não nos desenvolvíamos muito (FRANZEN, 2014).
}

Com a extinção do jornal impresso e criação da AG Comunique, mudanças ocorreram no conteúdo da disciplina. Lima introduziu a ideia de produção de conteúdos jornalísticos pelos seus alunos como o principal instrumento de avaliação, visando o desenvolvimento da escrita. A opção pela internet viabilizou também a publicação de uma quantidade maior de textos e reduziu custos. Além de a AG Comunique ser importante para o desenvolvimento dos alunos por seu conteúdo jornalístico, transcende a questão acadêmica. Para a professora Maurini de Souza, a agência tem um papel importante na formação acadêmica e social dos alunos. Para ela, "é o compartilhamento do aprendizado, tanto com os colegas como com a sociedade em geral. É romper muros da universidade e alcançar o mundo em que se pretende atuar" (SOUZA, 2014).

Numa instituição pública e gratuita, a contribuição social proporcionada pela agência torna seu funcionamento ainda mais interessante. Maurini afirma que a "AG Comunique é mais uma ferramenta que possibilita à universidade pública prestar serviços, ser útil à comunidade em geral. É extensão universitária, um quesito que ainda engatinha nas universidades brasileiras" (SOUZA, 2014). Quando questionada se agências experimentais estimulam o senso crítico do aluno, 
DITO EFEITO - ISSN 1984-2376 - v. 6, n. 8, jan./jun. 2015 - UTFPR CURITIBA - http://periodicos.utfpr.edu.br/de

Maurini afirma que "o grande trunfo é o compartilhamento do aprendizado, entre os próprios alunos e deles com a comunidade. Com a internet, o alcance é potencializado, fazendo com que o conteúdo produzido pelos alunos possa ser visto por usuários de várias partes do mundo" (SOUZA, 2014).

No curso de Comunicação Institucional, a agência representa um importante instrumento de prática ao jornalismo, fazendo com que o aluno experimente a profissão. A AG Comunique opera de forma semelhante a uma redação, inclusive no cumprimento de prazos, rotinas de trabalho e coleta externa de informações. Além disso, o estudante possui liberdade e autonomia para a criação e produção do conteúdo jornalístico. Na opinião da estudante Maria de Lourdes Figueiredo, "sem autonomia não há criação e desenvolvimento. Trata-se de um importante detalhe que incentiva a continuidade da produção" (FIGUEIREDO, 2014). O aluno Pedro Da Ré, integrante da turma que implantou a AG Comunique, também explica que a liberdade foi essencial para um melhor desenvolvimento acadêmico e pessoal:

[...] a autonomia, desde a busca pela pauta até a produção textual e visual, é, sem dúvida, importante para o desenvolvimento do sujeito e, apesar de se tratar de uma atividade acadêmica, os frutos e conhecimentos adquiridos com tal experiência auxiliaram também a nortear algumas decisões pessoais (DA RÉ, 2014).

Pedro conta ainda que, ao atuar na AG Comunique, pôde desenvolver tanto a compreensão sobre temas e pautas sobre os quais escreveu, quanto a técnica jornalística. Para Laís Sebben, também aluna do CTCOM e participante da agência no primeiro semestre de 2014, o período de prática foi importante por ser o jornalismo uma das áreas da comunicação em que ela mais tinha interesse. Ela afirma que a AG Comunique:

[...] auxiliou em meu crescimento como profissional da área de comunicação. Como eu já tinha um gosto maior pela área de jornalismo desde o início do curso, pude colocar em prática esse gosto e me senti muito feliz ao ter essa liberdade de poder publicar reportagens minhas em um site de notícias (SEBBEN, 2014).

A aluna salienta também a ponte entre a academia e o mundo do trabalho, vivenciado durante seu período na agência. "A AG Comunique me ajudou a perceber o mercado de trabalho de uma maneira bem mais real e próxima. A partir das minhas reportagens pude expor o meu trabalho para diferentes pessoas e jornalistas" (SEBBEN, 2014).

A agência também é avaliada de forma positiva pela aluna Jaqueline Modesto. Formada em Jornalismo e estudante de Comunicação Institucional, ela aproveitou a oportunidade e o alcance da AG Comunique. Mesmo não matriculada na disciplina de LPTJ, contribuiu na produção de conteúdo para a agência, fortalecendo ainda mais o veículo. A aluna colaborou principalmente com pautas de assuntos internos da universidade, que geralmente não são divulgados na grande imprensa. Suas reportagens abordaram, entre outros temas, o perfil de alunos e professores da UTFPR que desenvolveram projetos e pesquisas relevantes para a comunidade universitária. 
Jaqueline é um exemplo da importância da agência. Ela também mostra como pode ser interessante a veiculação de assuntos pouco difundidos nos grandes meios, mas que se tornam relevantes ao público que se relaciona com o tema. A aluna destaca a resposta que teve dos leitores: “[...] a alegria de ver que as pessoas gostavam e tinham interesse de ler meu texto. Pra mim foi uma satisfação contribuir para a AG Comunique" (MODESTO, 2014).

Para o professor Marcelo, a evolução dos alunos na disciplina, por meio da participação na agência, ocorre em quatro níveis:

[...] 1) um deles ocorre em se tratando do domínio de texto pelo aluno, com a prática de redação de notícias, notas, textos opinativos, reportagens. O exercício desse tipo de texto ajuda o aluno a ter uma ideia dos principais gêneros praticados no jornalismo impresso e de internet; 2) o aluno depura a sua visão sobre o que é e o que não é notícia. Com o exercício de produção textual mais frequente, ele assimila os principais critérios de noticiabilidade, ou seja, os fatores que determinam se um fato será ou não transformado em notícia; 3) o aluno aprende as principais técnicas de reportagem e entrevista; 4) todos esses conhecimentos são passados e discutidos com o professor, procurando fazer uma reflexão sobre os próprios pontos positivos e defeitos da mídia, como a tentativa de "fabricar" notícias para ludibriar o público. Nesse caso, entra a discussão da ética e do próprio papel social da mídia (LIMA, 2014).

O professor diz ainda que "a quarta etapa não é assimilada necessariamente por todos os alunos, principalmente porque alguns direcionam seus talentos para outras áreas da comunicação" (LIMA, 2014). Independente disso, acredita que a maioria dos alunos assimila os conhecimentos teóricos e práticos apresentados durante a disciplina, construindo uma visão mais crítica da atividade jornalística e da própria dificuldade que os veículos têm em manter temas de maior interesse social em pauta.

Para Marcelo, a experiência no processo de produção de notícias tem outro benefício: o de desmistificar a profissão de jornalista. Com isso, o aluno tem um maior conhecimento sobre a profissão que terá relevância para a sua vida profissional. Para Laís Sebben Xavier, isso fica claro quando afirma que:

[...] com a experiência da produção de textos jornalísticos aprendi que toda reportagem deve ouvir os dois lados em relação a um determinado assunto, um jornalista deve sempre abrir espaço para vertentes diferentes em um texto jornalístico e, assim, mostrar ao leitor um posicionamento imparcial e deixá-lo formar sua própria opinião. Também aprendi que uma reportagem deve ser sempre revisada, várias vezes, antes da publicação, evitando futuros erros de escrita que não poderão ser apagados se a reportagem for impressa.

Outro ponto que merece destaque é a percepção do aluno quanto ao seu processo de aprendizado durante o período em que participou da agência. Além do conhecimento direto, avaliado pelo professor durante a disciplina e traduzido em um método avaliativo, o aluno carrega consigo a experiência de vivenciar a agência e assim percebe seu própria desenvolvimento profissional, principalmente ao analisar qualitativamente a evolução em seus textos produzidos.

Somado ao aprendizado textual e jornalístico, o aluno pode ampliar seu conhecimento no aspecto social. O professor Marcelo, questionado se a agência poderia gerar uma reflexão dos 
alunos quanto às questões sociais, afirma:

[...] acredito que essa transformação pode ocorrer de duas formas. Uma delas acontece sobre o próprio aluno. Ao sair de sua "zona de conforto" e procurar informações de uma área ou com um grupo social que ele não conheça, tem a oportunidade de ampliar sua visão de mundo, de interagir com outros meios. Isso pode trazer, ao mesmo tempo, consciência social e uma visão mais clara de áreas sobre as quais tinha pouca informação (LIMA, 2014).

Um dos responsável pela Rede Teia, conjunto de veículos mantidos pelo curso de Jornalismo da Universidade Positivo, o professor Emerson Castro Firmo da Silva também acredita que esses meios incentivam os alunos a terem percepções críticas sobre o meio social em que vivem. Emerson destaca a importância de se pensar nesse contexto logo na formação acadêmica do aluno. O professor explica:

[...] é inevitável a tomada de consciência para a responsabilidade social ao relacionar-se com a sociedade, especialmente no papel de intermediador, por meio dos veículos que fazem parte de uma rede laboratorial. [...] Se considerarmos que os profissionais, que dela [A Rede Teia] saem formados, ali se tornaram mais conscientes de suas responsabilidades no exercício profissional, a relevância é enorme. Quem lida com comunicação e pretende fazê-lo para o bem da sociedade precisa ter essa consciência despertada na formação (SILVA, 2014).

A exposição dos alunos às questões sociais vão ao encontro da nossa busca em visitar as obras de Freire e entender melhor essa ideia. Exposto às contradições, o aluno passa a entender melhor sua realidade e a questioná-la. Em seguida, tende a buscar soluções. A ideia de Paulo Freire que o professor Marcelo Lima percebe mais próxima à agência é a de comunicação horizontalizada. Segundo ele,

[...] parte-se da noção de que, para haver comunicação, é preciso haver uma troca de igual para igual. Isso pode ser aplicado em relação à própria hierarquia da agência. Aquilo que sai publicado é fruto, às vezes, de uma longa conversa entre o professor e os alunos. E, a partir dessa troca, se dá o aprendizado (LIMA, 2014).

Outro ponto que o professor comenta sobre as proximidades das ideias de Freire com a agência é a preocupação com as mudanças sociais. "Paulo Freire entende o comunicador como um transformador da realidade social. Seu objetivo final é melhorar sua própria comunidade, e por isso não pode ser neutro. Embora difícil de ser ensinada, esta lição é bastante importante para a formação dos alunos" (LIMA, 2014). Fechando este ciclo da proximidade do autor estudado e a agência experimental de notícias, entendemos que a agência não foi criada com base propriamente dita em Paulo Freire, mas que seu objetivo final se assemelha com as ideias do pedagogo:

[...] as ideias de Freire são assimiladas naturalmente, pois seu discurso permeia, de certa forma, a própria base pedagógica das instituições em que desenvolvi veículos laboratoriais, ou seja, é preciso tornar o jornal ou a agência de comunicação um veículo com características comunitárias, onde tudo o que couber pode ser publicado, onde todos podem dar a opinião e indicar uma direção a ser seguida, desde que haja bom senso e desde que esteja dentro dos limites dos próprios propósitos do jornalismo (LIMA, 2014). 


\section{Considerações finais}

Apresentaremos a seguir algumas ideias que podem contribuir para um melhor aproveitamento e desenvolvimento da agência.

Como o curso possui matérias que se relacionam com diversas frentes da comunicação, os alunos podem se utilizar desses conhecimentos para melhorar a AG Comunique.

Estando a agência vinculada a um portal na web, é importante que a questão visual e a interatividade com o público leitor sejam aprimoradas e melhoradas. Com isso, entendemos que a matéria de Editoração Eletrônica pode contribuir.

Além disso, com a experiência e aprendizado dessas matérias, o jornal impresso poderia voltar a ser produzido - algumas matérias publicadas na AG Comunique poderiam ser reeditadas no jornal impresso. Feita esta organização, os alunos de Editoração Eletrônica poderiam produzir e diagramar o jornal, aumentando o alcance de público da própria agência.

Em relação a sua comunicação e interação com o público, os conhecimentos aprendidos na disciplina de Teoria de Relações Públicas podem contribuir, assim como as matérias de Linguagem Visual I e II podem contribuir na melhoria das qualidade das fotos e vídeos que acompanham as matérias jornalísticas. Já a disciplina Marketing pode contribuir na criação de estratégias de comunicação e divulgação da agência, melhorando esse produto do CTCOM.

Com o acréscimo dessa força-tarefa na AG Comunique, mais alunos podem se interessar em participar. Isso gera um melhor aproveitamento em relação à aquilo que o aluno mais gosta de produzir, bem como diferentes experiências nas múltiplas facetas da comunicação. Esse ir e vir de informação, conteúdo, prática e experiência permite que a agência se torne um veículo melhor e com alcance de público crescente.

Outro ponto que pode ser abordado é a questão da periodicidade na publicação de matérias. Como os alunos produzem o conteúdo no decorrer do semestre, há uma sazonalidade. Vários dias da semana ficam repletos de matérias, porém outros ficam sem nada publicado. O mesmo ocorre em tempo de férias. Organizando e planejando melhor os conteúdos e datas, será possível agendar publicações constantes e de diversos assuntos - aspecto importante principalmente no contexto online.

Por fim, sugere-se a melhoria na qualidade das matérias produzidas pelos alunos, por meio de maior incentivo por parte dos professores, bem como revisão mais cuidadosa, além de maior cobrança quando ao aprofundamento dos temas abordados nos textos.

\section{Referências}

BRASIL. Lei n ${ }^{\circ}$ 9.394, de 20 de dezembro de 1996.

COMUNICAÇÃO Institucional. Profissões - Comunicação e Informação. Guia do Estudante, 
DITO EFEITO - ISSN 1984-2376 - v. 6, n. 8, jan./jun. 2015 - UTFPR CURITIBA - http://periodicos.utfpr.edu.br/de

Editora Abril. Disponível em: <http://guiadoestudante.abril.com.br/ profissoes/comunicacaoinformacao/comunicacao-institucional-684653.shtml>. Acesso: 1 ago. 2014.

Conheça a UTFPR, a primeira universidade tecnológica do país. Disponível em $<$ http://redeglobo.globo.com/globouniversidade/noticia/2013/10/conheca-utfpr-primeirauniversidade-tecnologica-do-pais.html>. Acesso em: 1 ago. 2014.

DA RÉ, Pedro. Entrevista. Curitiba, UTFPR, 13 ago. 2014.

FIGUEIREDO, Maria de Lourdes. Entrevista. Curitiba, UTFPR, 14 ago. 2014.

FRANZEN, Luís Fernando. Entrevista. Curitiba, UTFPR, 13 ago. 2014.

FREIRE, Paulo. Educação e mudança. Rio de Janeiro: Paz e Terra, 1979.

. Pedagogia da autonomia: saberes necessários à prática educativa. 43 ed. Rio de Janeiro: Paz e Terra, 2011.

LIMA, Marcelo Fernando de. Entrevista. 13 ago. 2014.

LIMA, Venício Artur de. Comunicação e cultura: as ideias de Paulo Freire. 2. ed., rev. Brasília: Universidade de Brasília, 2011.

MODESTO, Jaqueline Carla. Entrevista. Curitiba, UTFPR, 17 ago. 2014.

SILVA, Emerson de Castro Firmo da. Entrevista. Curitiba, 17 ago. 2014.

SOUZA, Maurini de. Entrevista. Curitiba, UTFPR, 14 ago. 2014.

UTFPR. Projeto Pedagógico do Curso de Tecnologia em Comunicação Institucional. Departamento Acadêmico de Comunicação e Expressão (DACEX). Curitiba, 2013.

WOLF, Mauro. Teoria da comunicação de massa. São Paulo: Martins

Fontes, 2011.

XAVIER, Laís Sebben. Entrevista. Curitiba, UTFPR, 14 ago. 2014. 